\title{
PELATIHAN PEMANFAATAN SAMPAH DAUN KERING DAN SAMPAH SISA MAKANAN MENJADI PUPUK ORGANIK CAIR DALAM MEWUJUDKAN GREEN HOUSE DI METLAND TAMBUN CLUSTER FONTANIA
}

\author{
Fata Nidaul KHASANAH ${ }^{1}$, Syahbaniar ROFIAH², Didik SETIYADI ${ }^{3}$, Rizal Nanda REYNALDI ${ }^{4}$ \\ 1,3,4Teknik Informatika, STMIK Bina Insani \\ 2Manajemen Informatika, STMIK Bina Insani \\ Email: fatanidaul@gmail.com
}

\begin{abstract}
Settlements are one of the sources of contributors in the growing number of garbage. Handling waste done well in processing can provide benefits at once can reduce the buildup of existing garbage volumes. The purpose of this training is how to utilize dried leaf garbage and leftover waste food to be processed into liquid organic fertilizer that can provide benefits for the environment so as to preserve plants around the settlement to To a beautiful, fresh and green settlement so it is realized "Green House" in MetlandTambun Cluster Fontania. In the implementation of the methods used include counseling activities, training activities and mentoring activities. From the activities, the residents can utilize dried leaf garbage and food scraps waste to be processed into liquid organic fertilizer with the help of the counting machine and grinding machine in the manufacturing process.
\end{abstract}

Keywords: Dried leaves, Green House, counting machine, grinding machine, liquid organic fertilizer

\begin{abstract}
ABSTRAK
Permukiman merupakan salah satu sumber penyumbang dalam meningkatnya jumlah sampah. Penanganan sampah yang dilakukan dengan baik dalam pengolahannya dapat memberikan manfaat sekaligus dapat mengurangi penumpukan volume sampah yang ada. Tujuan dari pelatihan ini adalah bagaimana memanfaatkan sampah daun kering dan sampah sisa makanan untuk diolah menjadi pupuk organik cair yang dapat memberikan manfaat bagi lingkungan sekitar sehingga dapat melestarikan tanaman di sekitar permukiman untuk menuju sebuah permukiman yang asri, segar dan hijau sehingga terwujud "Green House" di Metland Tambun Cluster Fontania. Dalam pelaksanaannya metode yang digunakan meliputi kegiatan penyuluhan, kegiatan pelatihan dan kegiatan pendampingan. Dari kegiatan tersebut maka warga dapat memanfaatkan sampah daun kering dan sampah sisa makanan untuk diolah menjadi pupuk organik cair dengan bantuan mesin pencacah dan mesin penggiling dalam proses pembuatannya.
\end{abstract}

Kata Kunci: Daun Kering, Green House, Mesin Pencacah, Mesin Penggiling, Pupuk Organik Cair 


\section{PENDAHULUAN}

Volume sampah di Indonesia semakin meningkat seiring dengan bertambahnya jumlah penduduk. Sampah merupakan sisa kegiatan sehari-hari manusia dan atau proses alam yang bebentuk padat (Sari, Lestari, \& Awal, 2018). Meningkatnya jumlah sampah juga di alami di beberapa wilayah di Indonesia salah satunya di kabupaten Bekasi, dengan adanya penumpukan sampah ini dapat mengakibatkan munculnya permasalahan baru. Seperti dikutip pada laman berita online menyebutkan bahwa 1300 ton sampah Kabupaten Bekasi tidak terangkat dalam sehari hal ini dikarenakan kurangnya jumlah armada pengangkut sampah yang tidak dapat menyeimbangi jumlah sampah yang dihasilkan serta terbatasnya lahan tempat pembuangan akhir sampah (Syaripudin, 2019).

Permukiman merupakan salah satu sumber sampah yang cukup besar peranannya dalam peningkatan volume sampah. Tujuhpuluh lima persen sampah yang dihasilkan di sekitar permukiman warga adalah jenis sampah organik yang berupa sampah daun-daun kering yang gugur, sampah sisa makanan dan sampah sisa sayuran (Khasanah \& Rofiah, 2019).

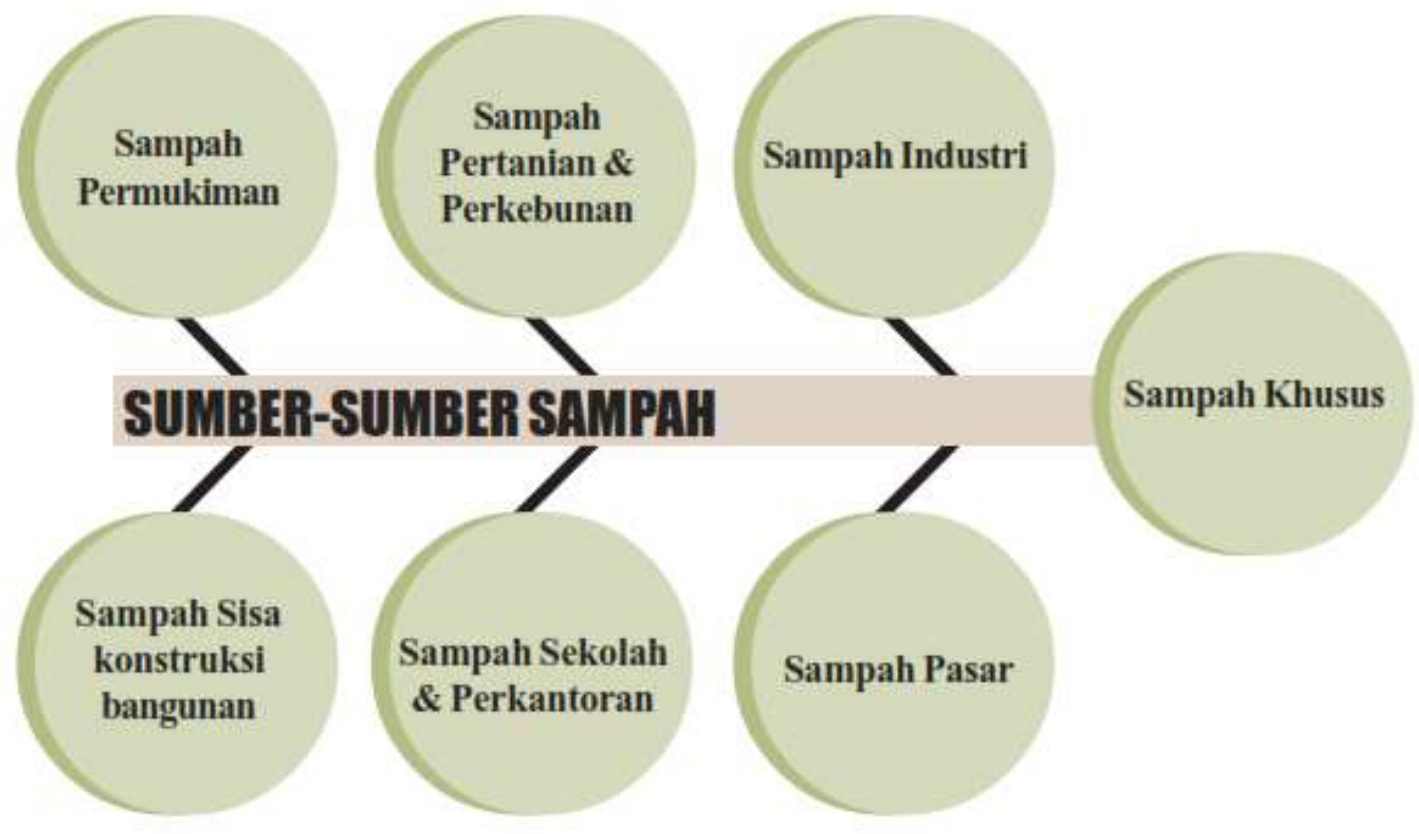

Sumber: (Nugroho, 2018)

Gambar 1. Sumber-sumber Sampah

Sejatinya keberadaan sampah saat ini apabila dapat ditangani dan diolah dengan baik dan benar sampah dapat menghasilkan sesuatu yang dapat memberikan manfaat sebagai contoh sampah yang terdapat di sekitar permukiman rumah tangga apabila diolah dapat menghasilkan pupuk. Pupuk merupakan bahan yang ditambhakan ke dalam tanah yang nantinya dapat mempengaruhi pertumbuhan tanaman yang berasal unsur-unsur esensial yang dihasilkan oleh pupuk (Khasanah \& Rofiah, 2019).

Salah satu permukiman di daerah Metland Tambun Cluster Fontania yang dijadikan sebagai mitra dalam kegiatan Pengabdian Kepada Masyarakat. Pemilihan ini didasarkan pada hasil observasi menunjukkan bahwa terdapat warga yang mulai sadarakan pentingnya pengolahan sampah yang ada di lingkungan sekitar agar dapat menghasilkan sesuatu yang lebih bermanfaat bagi lingkungan sekitar. Hal yang dilakukan oleh warga tersebut adalah melakukan pemanfaatan sampah daun kering untuk diolah menjadi pupuk organik cair. Namun dalam pelaksanaannya terdapat permasalahan yang dihadapi oleh mitra diantaranya 1) penggunaan alat selama proses pengolahan pupuk yang masih 
manual dan sederhana, 2) proses pembusukan atau proses inkubasi untuk menghasilkan pupuk organik cair memerlukan waktu yang cukup lama.

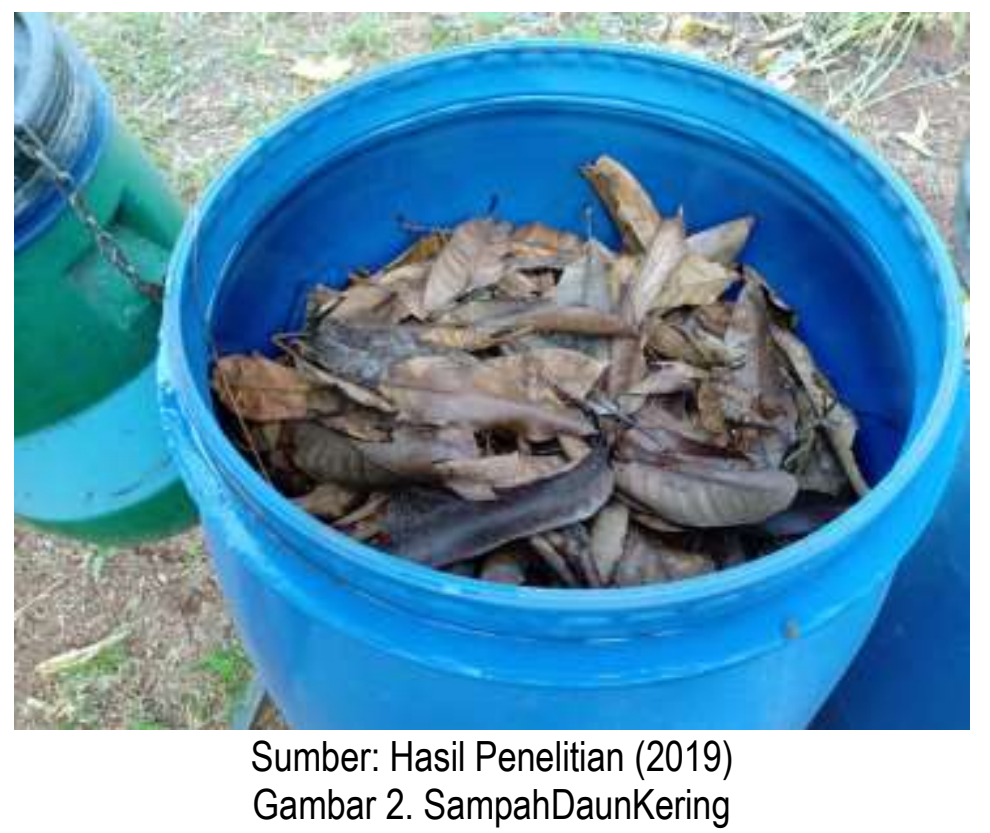

Berdasarkan permasalahan yang terjadi pada mitra maka diperlukan adanya gagasan yang dapat membantu dalam penyelesaian masalah mitra. Inovasi teknologi merupakan salah satu gagasan yang diusulkan untuk membantu dalam penyelsaian masalah mitra dalam proses pengolahan pupuk. Inovasi teknologi yang diusulkan adalah adanya mesin pencacah sampah kompos. Selain memanfaatkan sampah daun kering juga perlu memanfaatkan sampah sisa makanan yang ada, hal ini dilakukan agar proses pembusukan dalam pengolahan pupuk lebih cepat. Agar pencampuran antara sampah daun kering dan sampah sisa makanan tercampur merata maka diperlukan adanya mesin penggiling sampah. Untuk itu diperlukan adanya kegiatan pelatihan dan pendampingan dalam pemanfaatan sampah daun kering dan sampah sisa makan agar dapat diolah untuk menghasilkan pupuk organik cair dengan baik.

Kegiatan pelatihan yang berkaitan dengan proses pengolahan sampah agar dapat diamnfaatkan menjadi suatu yang bermanfaat telah dilakukan oleh beberapa peneliti-peneliti sebelumnya. Kegiatan edukasi dan pengelolaan sampah model sentralisasi kepada masyarakat Dusun Dan dangan Kecamatan Deket Kabupaten Lamongan dilakukan melalui proses penyuluhan masyarakat dan pelatihan masyarakat, hasil dari pelatihan ini berupa meningkatnya kesadaran masyarakat sekitar dalam pengelolaan sampah dengan membungkus sampah dan diletakkan kedalam tong sebelum sampah diambil dan dibuang ke tempat pembuangan akhir (Setiawan \& Rahman, 2019). Pengelolaan sampah rumah tanggan di lingkungan RT. 1 - 14/RW IV Kelurahan Rungkut Menanggal Kecamatan Gununganyar Kota Surabaya bertujuan untuk memberikan nilai tambah sampah dengan menjadikannya pupuk organik selain itu dengan kegiatan ini dapat mengurangi volume sampah sehingga secara tidak langsung kegiatan ini dapat membantu pemerintah Surabaya dalam mengurangi jumlah sampah kota Surabaya, kegiatan ini dilakukan melalui kegiatan penyuluhan, pelatihan dan pendampingan, hasil yang diperoleh adalah sampah yang terdapat di lingkungan sekitar dapat bermanfaat menjadi pupuk organik yang bernilai ekonomis (Siswati \& Edahwatu, 2017). Pengelolaan sampah organik yang baik juga dapat mewujudkan ingkungan yang hijau di sekitar kampus, hal ini juga dilakukan pada Universitas Lancak (Sari et al., 2018). 
Tujuan dari pelatihan ini adalah bagaimana memanfaatkan sampah daun kering dan sampah sisa makanan untuk diolah menjadi pupuk organik cair yang dapat memberikan manfaat bagi lingkungan sekita rsehingga dapat melestarikan tanaman di sekitar pemukiman untuk menuju sebuah pemukiman yang asri, segar dan hijau sehingga terwujud "Green House" di Metland Tambun Cluster Fontania.

\section{METODE PELAKSANAAN}

Metode yang dilakukan dalam pengabdian kepada masyarakat untuk skema program kemitraan masyarakat ini terdiri dari kegiatan penyuluhan, pelatihan dan pendampingan.

Dalam kegiatan penyuluhan dilakukan dengan menjelaskan dari tujuan pelaksanaan kegiatan ini yaitu berupa pemanfaatan sampah daun kering dan sampah sisa makanan untuk diolah sehingga menghasilkan pupuk organik cair. Dari pupuk organik cair yang dihasilkan dapat memberikan manfaat bagi lingkungan sekitar berupa pemberian pupuk terhadap tanaman sekitar sehingga mewujudka nlingkungan yang asri, bersih dan hijau.

Selanjutnya dalam kegiatan pelatihan dilakukan demonstrasi mengenai bahan apa saja yang diperlukan dalam proses pengolahan pupuk, bagaimana cara mengolah pupuk dengan memanfaatkan sampah daun kering dan sampah sisa makanan dengan menggunakan mesin pencacah sampah dan mesin penggiling sampah.

Kegiatan pendampingan dilakukan untuk memantau ketrampilan warga sekitar dalam melakukan pengolahan sampah sudah berjalan sesuai dengan kegiatan pelatihan. Selain itu kegiatan pendampingan juga bertujuan untuk melihat sejauh mana proses pengolahan pupuk telah dilakukan oleh warga sekitar.

Dalam kegiatan ini bantuan alat yang diberikan berupa mesin pencacah sampah dan mesin penggiling sampah untuk itu dalam pelatihan dijelaskan mengenai penggunaan dan perawatan dari kedua mesin tersebut. Selain itu untuk mendukung proses pengolahan pupuk juga diberikan bantuan alat berupa pengadaan tong komposter untuk menampung dari bahan yang nantinya akan diproses menjadi pupuk.

\section{HASIL DAN PEMBAHASAN}

Setelah warga sekitarmengetahui tujuan dari kegiatan ini melalui kegiatan penyuluhan maka proses selanjutnya masuk ketahap kegiatan pelatihan.

Kegiatan pelatihan bertujuan untuk menjelaskan bagaimana proses pengolahan pupuk dengan memanfaatkan sampah daun kering dan sampah sisa makanan dapat dilakukan.

Dalam kegiatan pelatihan ini terdapat beberapa tahapan yang dilakukan untuk melakukan proses pengolahan pupuk diantaranya: 1) Menyiapkan bahan,2) menyiapkan molase, 3) proses pengolahan pupuk dengan menjelaskan bagaimana penggunaan mesin pencacah sampah, penggunaan mesin penggiling sampah dan memasukkan ke dalam komposter

Dalam menyiapkan bahan adapun bahan utama yang digunakan dalam proses pengolahan pupuk ini, yaitu dengan memanfaatkan sampah daun kering dan sampah sisa makanan yang terdapat di permukiman sekitar. 


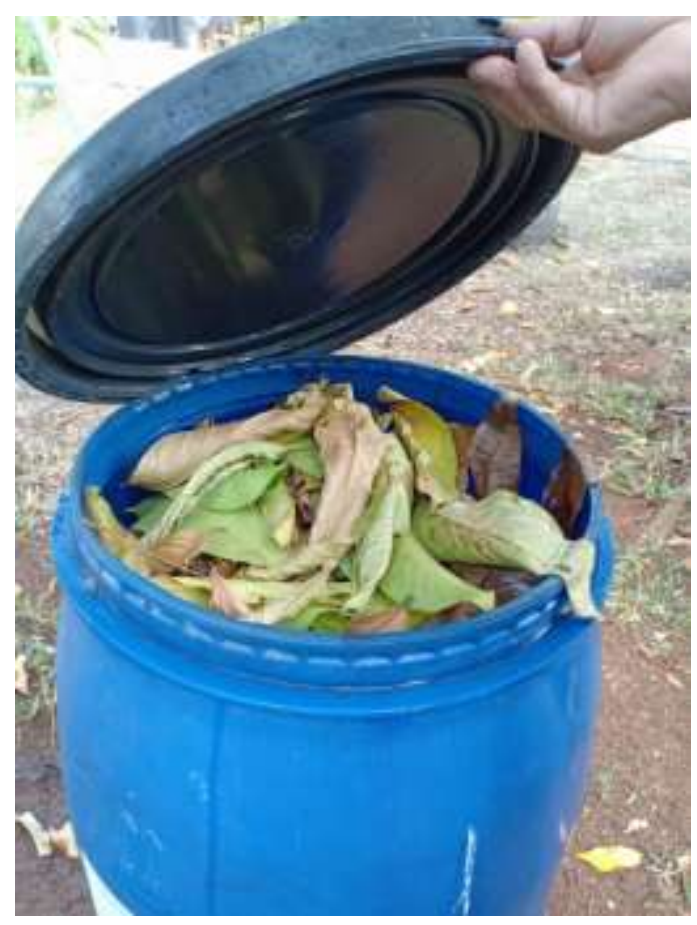

Sumber: Hasil Penelitian (2019)

Gambar 3. Bahan Utama Sampah Daun Kering

Setelah bahan sudah disiapkan maka tahap selanjutnya adalah menyiapakan molase atau mikro organisme, adapun bahan yang dibutuhkan yaitu denga nmencampurkan gula pasir, air dan terasi menjadi satu serta EM4.

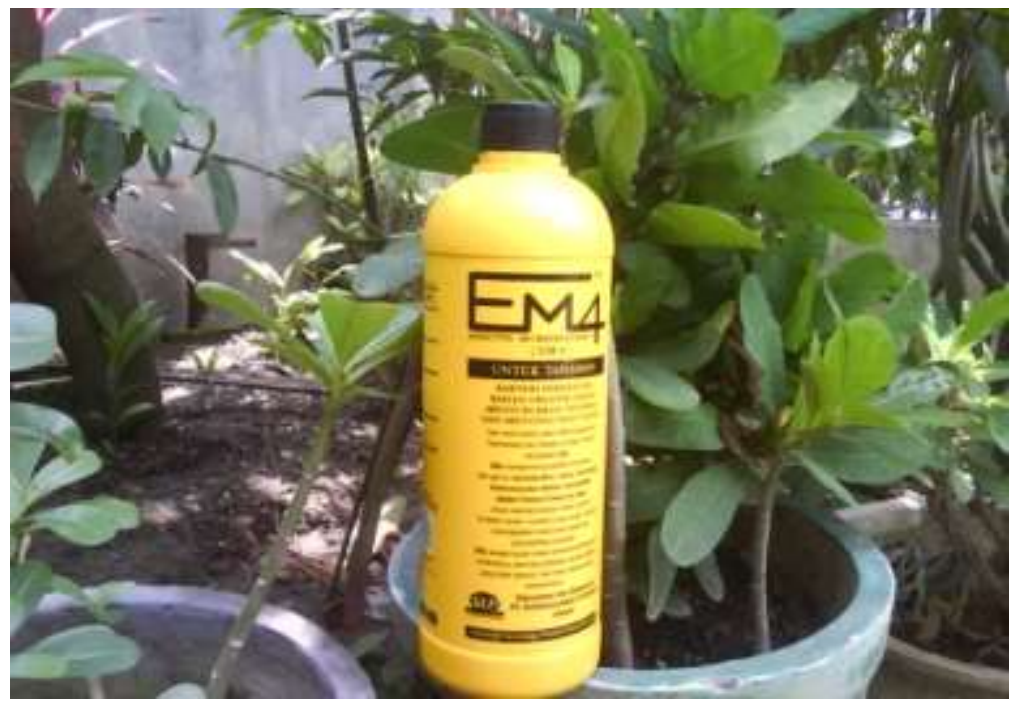

Sumber: Hasil Penelitian (2019)

Gambar 4. EM4

Bahan yang akan diolah menjadi pupuk perlu dicacah terlebih dahulu, untuk pencacahan sampah daun kering dalam kegiatan ini menggunakan mesin pencacah sampah kompos. Kegiatan pencacahan bertujuan agar bahan sampah daun kering yang dijadikan bahan dalam proses pengolahan pupuk telah tercacah sehingga proses dekomposisinya lebih cepat dibandingkan dengan sampah daun kering yang masih utuh. 


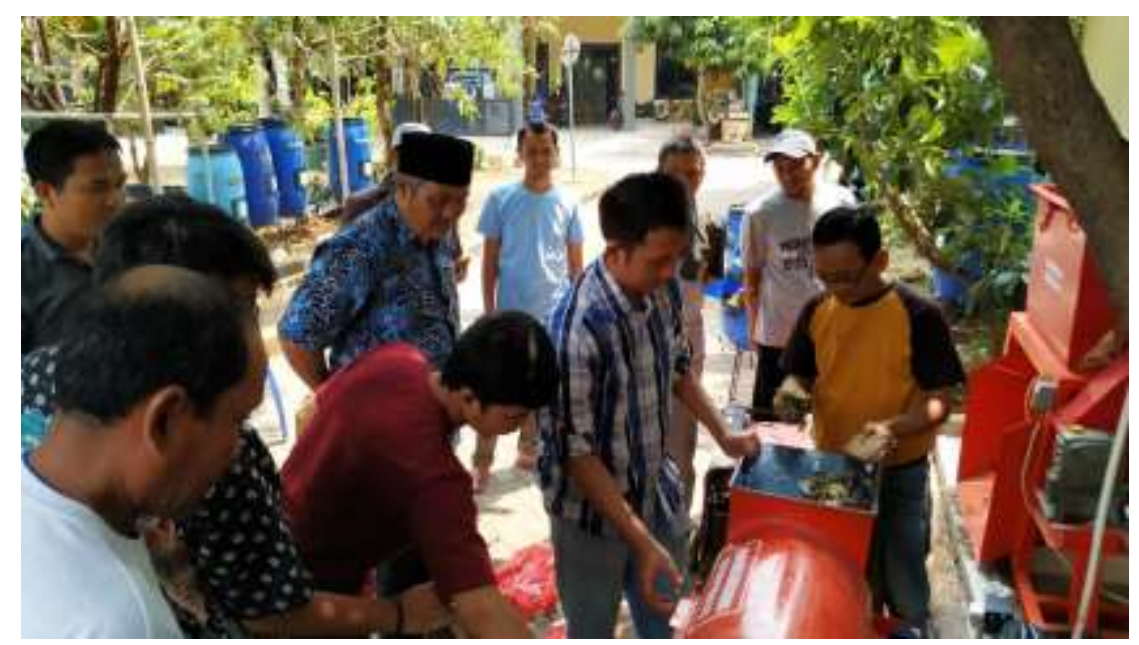

Sumber: Hasil Penelitian (2019)

Gambar 5. Pelatihan Pengoperasian Mesin Pencacah Sampah

Setelah bahan tercacah sehingga memiliki ukuran yang lebih kecil maka proses selanjutnya adalah melakukan pengadukan. Proses pengadukan dilakukan agar bahan pengolahan sampah dapat tercampur merata sehingga bersifat homogen. Dalam proses pengadukan menggunakan mesin penggiling sampah hal ini bertujuan agar proses penggilingan bisa dilakukan lebih mudah dan lebih merata dibandingkan ketika proses penggilingan dilakukan secara manual.

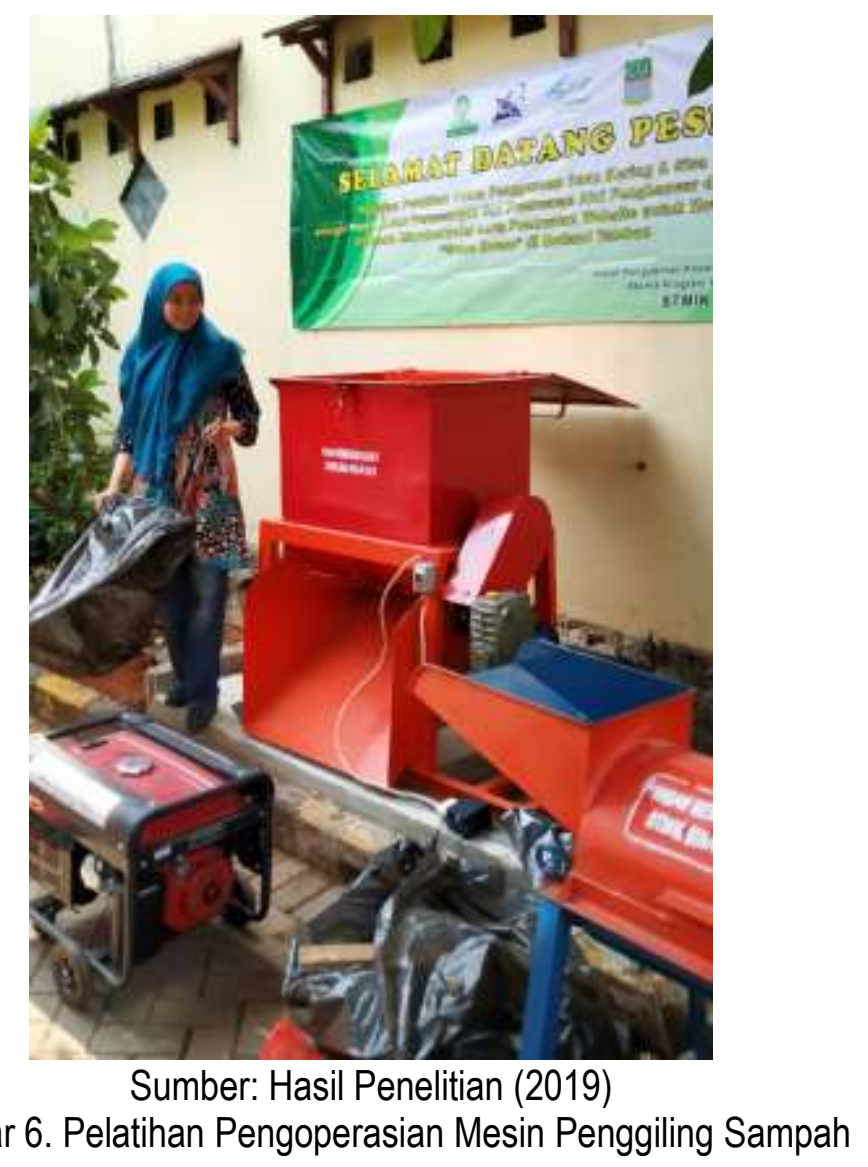

Setelah kegiatan pelatihan selesai maka kegiatan selanjutnya yang dilakukan adalah melakukan pendampingan kepada warga dalam proses pengolahan pupuk. Kegiatan ini dilakukan untuk melihat apakah tahapan yang dilakukan dalam melakukan pengolahan pupuk sudah benar dilakukan dan untuk 
mengetahui bagaimana perkembangan dari hasil proses pengolahan pupuk yang telah dilakukan. Gambar 7 menunjukkan kegiatan peserta dalam proses pengolahan pupuk dengan memasukkan bahan berupa sampah daun kering dan sampah sisa makanan yang telah tercacah dan tergiling dengan menggunakan mesin pencacah sampah dan mesin penggiling sampah untuks elanjutnya dimasukkan ke dalam komposter dengan menambahkan cairan molase dan EM4 yang telah tercampur.

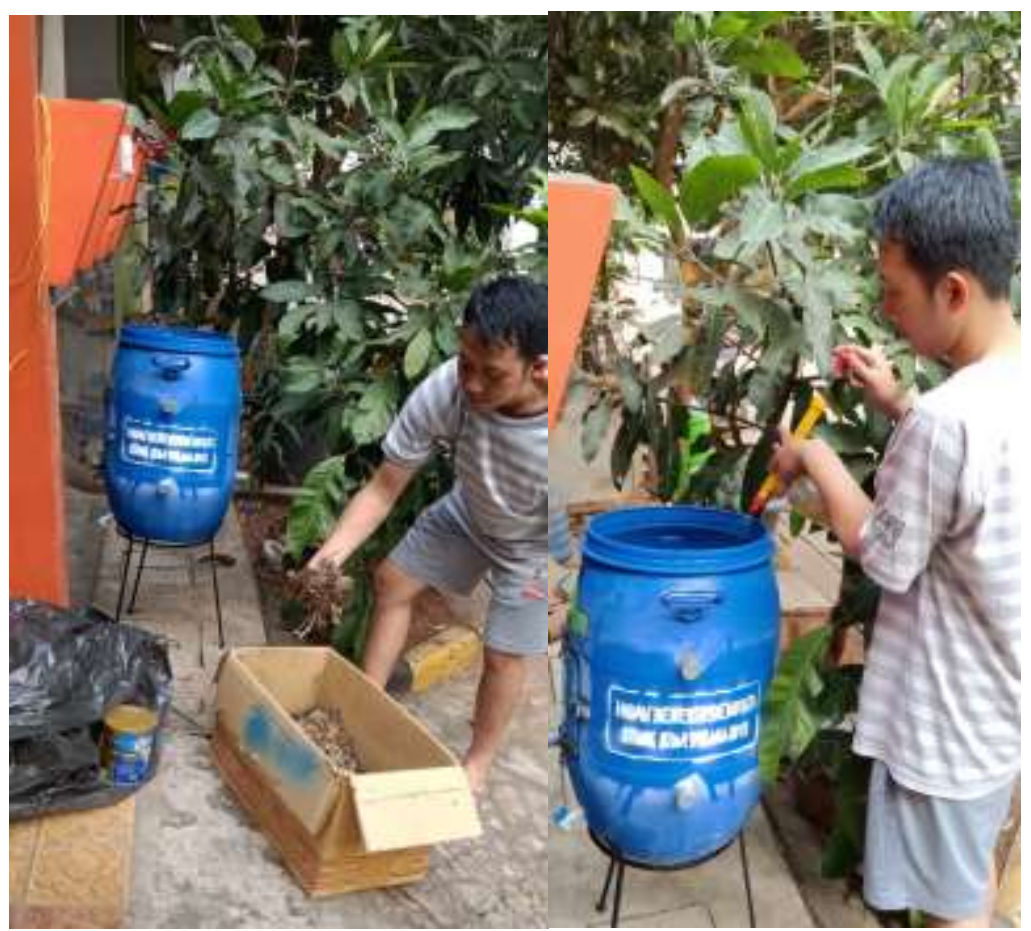

Sumber: Hasil Penelitian (2019)

Gambar 7. Proses PengolahanPupuk

Dari hasil pengolahan sampah maka selanjutnya menunggu proses pembusukan yang sempurna sampai akhirnya menghasilkan pupuk organikcair. Dari pupuk organik cair yang dihasilkan diharapkan dapat dimanfaatkan untuk tanaman sekitars ehingga menjadi subur dan lingkungan menjadi bersih sehingga terwujud lingkungan rumah hijau atau green house. Gambar 8 menunjukkan kondisi bahan dalam komposter selama proses inkubasi dilakukan. 


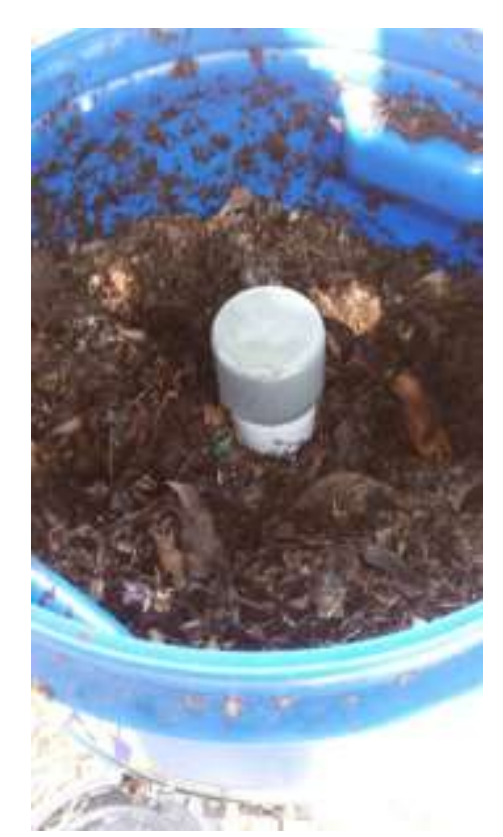

Sumber: Hasil Penelitian (2019)

Gambar 8. Kondisi Bahan Proses Inkubasi

Dari hasil kegiatan program kemitraan masyarakat yang telah dilakukan maka dapat diperoleh perbandingan antara sebelum dan sesudah kegiatan ini dilakukan. Tabel 1 menunjukkan perbandingan antara kondisi sebelum dan sesudah kegiatan program kemitraan masyarakat ini dilakukan.

Tabel 1. Perbandingan Sebelum Dan Sesudah PKM

\begin{tabular}{|c|c|}
\hline Sebelum PKM & Sesudah PKM \\
\hline $\begin{array}{c}\text { Bahan sampah daun kering yang digunakan } \\
\text { masih berbentuk utuh }\end{array}$ & $\begin{array}{c}\text { Bahan sampah daun kering telah tercacah } \\
\text { sehingga memiliki ukuran yang lebih kecil }\end{array}$ \\
\hline $\begin{array}{c}\text { Belum terdapat mesin pencacah sampah daun } \\
\text { kering }\end{array}$ & Terdapat mesin pencacah sampah daun kering \\
\hline $\begin{array}{c}\text { Tidak dilakukan pencampuran bahan antara } \\
\text { sampah daun kering dengan sampah sisa } \\
\text { makanan }\end{array}$ & $\begin{array}{c}\text { Dengan adanya mesin penggiling sampah maka } \\
\text { terjadi proses pencampuran antara sampah daun } \\
\text { kering dan sampah sisa makanan dapat dilakukan } \\
\text { secara merata dan homogen }\end{array}$ \\
\hline $\begin{array}{c}\text { Proses inkubasi harus menungu daun terurai } \\
\text { dan bahan tidak tercampur merata }\end{array}$ & $\begin{array}{c}\text { Proses inkubasi dapat langsung terjadi karena } \\
\text { bahan telah tercacah dan tercampur merata }\end{array}$ \\
\hline
\end{tabular}

Sumber: Hasil Penelitian (2019)

\section{SIMPULAN}

Kegiatan program kemitraan masyarakat dilakukan dengan menggunakan metode penyuluhan, pelatihan dan pendampingan kepada masyarakat. Kegiatan ini dilakukan agar warga dapat memanfaatkan sampah daun kering dan sampah sisa makanan yang terdapat di lingkungan sekitar dapat diolah sehingga menghasilkan sesuatu yang memiliki nilai guna yaitu berupa pupuk organik cair. Dari kegiatan ini warga dapat mengetahui bahan yang diperlukan dalam proses pengolahan pupuk, proses penggunaan mesin pencacah sampah dan mesin penggiling sampah serta manfaat dari kedua mesin tersebut dalam proses pengolahan pupuk. Adapun hal yang dapat dilakukan selanjutnya untuk dapat meningkatkan penelitian ini adalah perlu adanya pelatihan yang nantinya dapat memberikan manfaat dari sisi bagaimana cara melatih warga untuk dapat memasarkan produk yang 
dihasilkan sehingga dapat menambahkan nilai ekonomi dari proses pengolahan pupuk yang telah dilakukan.

\section{UCAPAN TERIMAKASIH}

Penulis mengucapkan banyak terima kasih kepada Direktorat Riset dan Pengabdian Masyarakat Kementrian Riset, Teknologi dan Pendidikan Tinggi yang telah membiayai penelitian ini untuk skema Program Kemitraan Masyarakat Tahun Anggaran 2019. Keputusan Dirjen Penguatan Risbang Nomor 8/E/KPT/2019 tentang Penerima Pendanaan Pengabdian kepada Masyarakat Tahun 2019. Selain itu terima kasih penulis ucapkan kepada Mitra dan Warga Metland Tambun Cluster Fontania kegiatan Pengabdian Masyarakat yang telah membantu dalam kelancaran kegiatan ini.

\section{REFERENSI}

Khasanah, F. N., \& Rofiah, S. (2019). Metode User Centered Design dalam Merancang Tampilan Antarmuka Ecommerce Penjualan Pupuk Berbasis Website Menggunakan Aplikasi Balsamiq Mockups. Jurnal Aplikasi Sains Dan Teknologi, 3(2), 14-23. https://doi.org/http://dx.doi.org/10.33366/jast.v3i2.1443

Nugroho, P. (2018). Panduan Membuat Pupuk Kompos Cair. Yogyakarta: Pustaka Baru Press.

Sari, M., Lestari, S. U., \& Awal, R. (2018). Peningkatan Ketrampilan Mahasiswa Dalam Pengelolaan Sampah Organik Untuk Mewujudkan Green Campus Di Universitas Lancang Kuning. Dinamisia : Jurnal Pengabdian Kepada Masyarakat, 2(2), 193-196.

Setiawan, G., \& Rahman, T. (2019). Edukasi dan Pengelolaan Sampah Model Sentralisasi Kepada Masyarakat Dusun Dandangan Kecamatan Deket Kabupaten Lamongan Melalui Peran Serta Karang Taruna ARDAS (Arek Dandangan Asli). JAST : Jurnal Aplikasi Sains Dan Teknologi, 3(1), 24. https://doi.org/10.33366/jast.v3i1.1272

Siswati, N. D., \& Edahwatu, L. (2017). Pengelolaan Sampah Rumah Tangga di Lingkungan RT.1 RT.14/RW. IV Kelurahan Rungkut Menanggal Kecamatan Gununganyar Kota Surabaya. Jurnal Aplikasi Sains Dan Teknologil, 1(1), 37-43.

Syaripudin. (2019). Sehari 1.300 Ton Sampah Kabupaten Bekasi tak Terangkut. Retrieved September 16, 2019, from https://indopos.co.id/read/2019/08/12/186248/sehari-1-300-ton-sampahkabupaten-bekasi-tak-terangkut/ 